\title{
Training and Coaching Model Design as A Solutions for Women's Microentrepreneurs Community (KOTA PELANGI) Problems
}

\author{
Nurul Asiah', Wahyudi David ${ }^{2}$, Tuti Widiastuti ${ }^{3}$ \\ 1,2Food Science and Technology Department, Universitas Bakrie \\ ${ }^{3}$ Communication Department, Universitas Bakrie \\ Jl. H.R, Rasuna Said Kav C-22, Kuningan, Jakarta 12920, Indonesia \\ E-mail: 1nurul.asiah@bakrie.ac.id, 2wahyudi.david@bakrie.ac.id, 3tuti.widiastuti@bakrie.ac.id
}

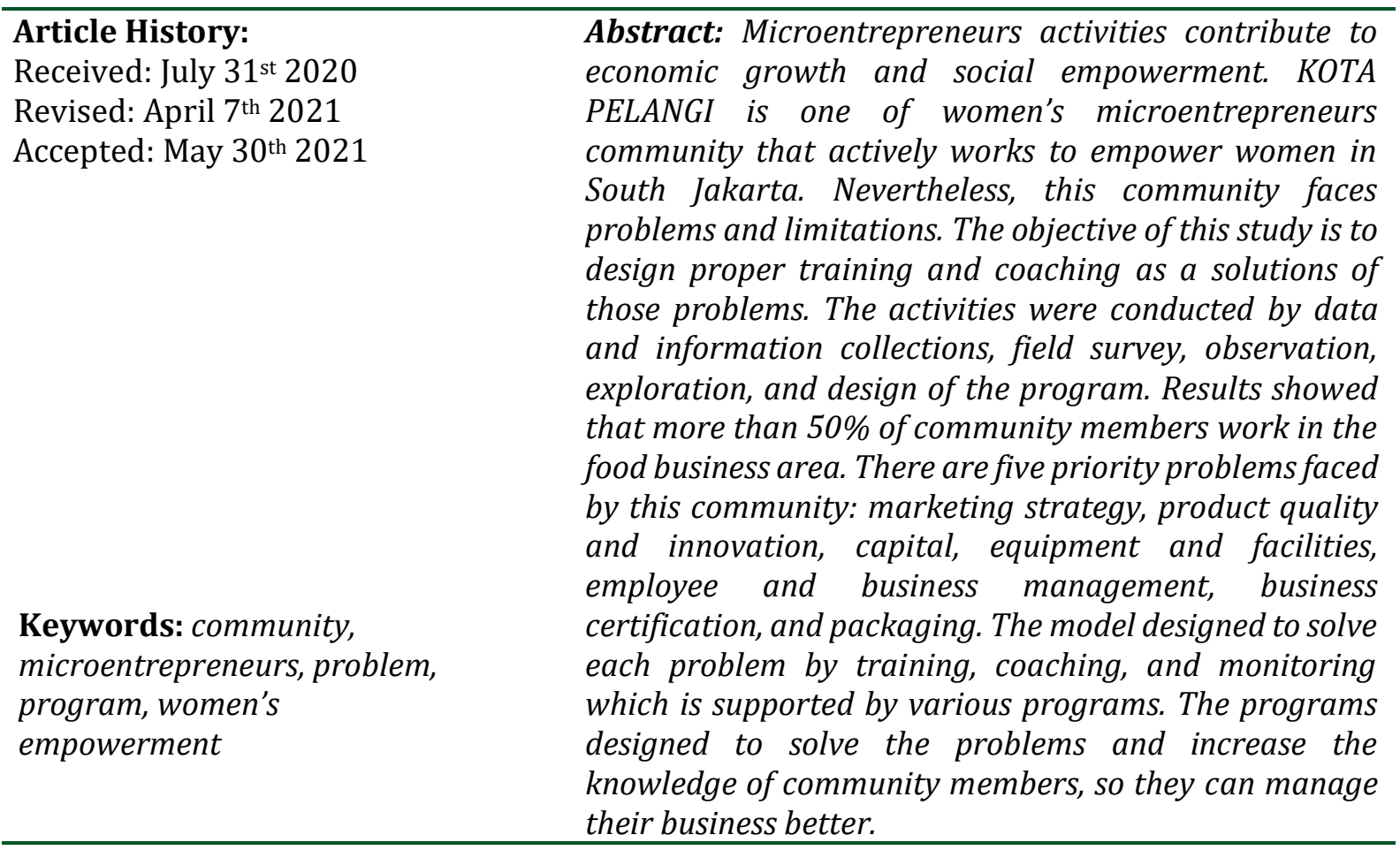

\section{Introduction}

Women are one of the most important pillars in human's lives, nation and state who have a very big role in building civilization. Until now there are still many women who have limited skills and education to get better opportunities and job opportunities. In addition, in the informal sector, protection and social security for working women are also still low ${ }^{1}$. Opportunities to achieve gender equility can be important aspect in

1 Tona Aurora Lubis, Zulkifli, and Erwita Dewi "Peningkatan Ketrampilan Manajemen dan Softskill Penjual Jamu Gendong di Kota Jambi”. Jurnal Pengabdian pada Masyarakat 30, no. 3 (2015). 
communities to deal with changes in society and the environment ${ }^{2}$. Women's empowerment and gender equility are central issue since women as individually and collectively become active, knowledgeable and goal oriented ${ }^{3}$. Entrepreneur's activities are one of many strategies to empower the women. Women have more control over domestic resources, social mobility, social activities, participation in household decision and participation in health related decition ${ }^{4}$. Micro, small and medium sized-enterproses (SMEs) are essential source of jobs. More over, empowering women entrepreneurs potentialy increase incomes, help poverty reduction, and lead to greater economic and social transformation.

The introduction of appropriate technology and the development of product innovation have been proven to be able to increase the productivity and business profits of drying the sago flour of the people of West Kalimantan ${ }^{5}$. Community empowerment based on the home food technology model has succeeded in encouraging these food houses to be productive, high-performing, skilled and economically independent ${ }^{6}$. The research study show that women's business decisions are influenced by: 1) a desire to strengthen their partner's responsibilities as a primary financial provider; 2) efforts to cover basic family daily needs; and 3) prepare for long term saving7. There are several reasons affecting women's enterpreneurship. The reasearch found "hold on to life by oneself" is the balance factor, "prove oneself and inovation" is push factor, "justice and dream" is both pull and push factor, and "mobbing" is emotional factor ${ }^{8}$.

A common problems faced by small entrepreneurs are maintaining product quality and finding the right marketing place ${ }^{9}$. In addition, people also experience limited

${ }^{2}$ Alessandra Galie, Nils Teufel, Amy Webb Girard, Isabelle Baltenweck, Paula Dominguez-Salas, Mindy J. Price, Rebecca Jones, Ben Lukuyu, Luke Korir, Ilana G. Raskind, Kristie Smith, and Kathryn M. Yount. "Women's empowerment, food security and nutrition of pastoral communities in Tanzania". Global Food Security 23 (2019): 125-134.

${ }^{3}$ Aleksandra Vujko, Tatiana N. Tretiakova, Marko D. Petrovic, Milan Radovanovic, Tamara Gajica, and Darko Vukovic. "Wowen's empowerment through self-employment in tourism". Annals of Tourism Research, 76 (2019): 328-330.

${ }^{4}$ Farawa Morshed. "Impact of Women Enterpreneurship on Women Empowerment in Bangladesh". Journal of Economics and Sustainable Development 6, no. 1 (2015): 1-9.

${ }^{5}$ Sholahuddin, Josua Parulian Hutajulu, and Evi Gusmayanti. "Peningkatan Produktivitas Usaha Pengeringan Tepung Sagu Masyarakat melalui Introduksi Teknologi Tepat Guna di Kalimantan Barat”. Jurnal Pengabdian pada Masyarakat 3, no. 2 (2018).

6Sunarti., Endriani, and Ajidirman. "Pemberdayaan Masyarakat Berbasis Teknologi Model Rumah Pangan Lestari di Kecamatan Kumpeh Ulu”. Jurnal Pengabdian pada Masyarakat 30, no. 1 (2015).

${ }^{7}$ Sophia Friedson-Ridenour, and Rachael S. Pierotti. “Competing priorities: Women's microenterprises and household relationships". World Development 121 (2019): 53-62.

${ }^{8}$ Fahri Ozsungur. "A research on women's entrepreneurship motivation: Sample of Adana Province”. Women's Studies International Forum 74 (2019): 114-126.

${ }^{9}$ Harri Santoso, Anita, Muliadi and Debi Agus Mayanti "Community Economic Empowerment through Cultivation of Enceng Gondok Program Using Community Engagement Program Approach in West Aceh Regency Post Conflict and Natural Disaster Eartquake and Tsunami 2004". Jurnal Pengabdian pada Masyarakat 3, no. 2 (2018). 
access to capital, lack of understanding of business finance management, products and packaging that are not standardized, the absence of trademarks, and the small capacity of production ${ }^{10}$. Simple calculation of business feasibility can be given in implementing extension activities and training in business development of processed food products ${ }^{11}$. Community empowerment can also be done by providing business and technical management assistance ${ }^{12}$.

Pancoran is one of the sub-districts in South Jakarta-Indonesia with a huge amount population density. The density of the population sometimes creates its own problems. On the other hand, this condition can also be seen as a market opportunity. There are still many people in the middle to lower economic levels, where most women of young mothers in productive age do not have permanent jobs, but they have great potential to be developed. KOTA PELANGI is a community initiated by women's in Pancoran to accommodate women entrepreneur activities. KOTA PELANGI is expected to be a role model for women specifically in the Pancoran region and throughout Indonesia widely related to self-reliance in entrepreneurship.

However, there are some obstacles in carrying out the business, including: 1). product quality consistency, 2). limitation of equipment and facilities, 3). less labelling and packaging technology, 4). lack of marketing strategy, 5). no busines manajement, 6). llimited capital information and business lisencing. Until now there have been many women entrepreneurship training programs. But the evidence regarding the impact of these programs is limited. That why designing programs that effectively facilitate women entrepreneurs to grow rapidly is still becomes big home work that has not been resolved yet.

To face the chalanges properly and achieve the expectation, it is deemed necessary to design proper model of training and coaching program to empowering women in running microentrepreneurs. Based on the background of the conditions of the partners' problems, there are several solutions offered in this service program, including through a gradual approach of training and coaching that will be realized by this research activities.

\footnotetext{
${ }^{10}$ Besse Wediawati and Rike Setiawati. "IbM Kelompok Usaha Bersama Perempuan Kepala Keluarga (KUBE-PEKKA) Di Kecamatan Telanai Pura Kota Jambi”. Jurnal Pengabdian pada Masyarakat 30, no. 1 (2015).

${ }^{11}$ Yusma Damayanti, Suandi, and Emi Kernalis. "Pelatihan dan Penyuluhan Pembuatan Telur Itik Asin Dalam Upaya Pengembangan Kewirausahaan Baru di Desa Tanjung Harapan Cupak Kecamatan Danau Kerinci Kabupaten Kerinci". Jurnal Pengabdian pada Masyarakat 30, no.4 (2015).

${ }^{12}$ Ade Octavia, Ida Masriani, and Sry Rosita. "Pemberdayaan Masyrakat Melalui Optimalisasi Program Bank Sampah Dengan Bantuan Teknis dan Manajemen Usaha Pada KSM Aneka Limbah dan KSM Maidanul Ula Kota Jambi". Jurnal Pengabdian pada Masyarakat 30, no. 3 (2015).
} 


\section{Method}

The community service activities was used Participatory Action Research (PAR) approached, where researchers and participants working together to find and understand the problems and use it to create solution for better condition. PAR involves researchers and community doing research collaboratively, formulating problems simultaneously, planning actions and carrying out activities continuously. Applying PAR method typically goes through a cycle of Observation, Action, Reflection and Evaluation. The observation is an activity to determine the condition of the subject research. The action includes establish relationships and common agenda with all stakeholders, collaboratively decide on issues, Collectively design research processes and tools, etc. Next step is Reflection and Evaluation. Reflection can be done in research design, ethics, knowledges and accountability, research questions, design, working relationships, etc. Evaluation is done through process and result evaluation. Process evaluation is carried out at each step of mentoring. This is to find out to what extent the process has taken place as expected. In practical, there is no blueprint for must-have methods or steps to go through because PAR is flexible in use. It means that in practical, condition sometimes change, and questions might change, as everyone in the group puts their learning into the ring 13,14 .

In practical, the whole community service activities conducted by five stages. The first stage was searching data and information or literature review. The activities cover collect, summarize, process, and analize data from various studies. Literature used in research $80 \%$ of this comes from several electronics international databases. In addition, $20 \%$ of the entire literature is used comes from book sources, references that have ISSN and ISBN, or official government website and international organizations. To perform a literature review, several search term was used i.e. women empowerment, community development, women enterpreneurs, micro enterpreneurs, and creative economy. The second stage was field survey to Komunitas Wanita Pengusaha Jualan Dagangan Mandiri or commonly called KOTA PELANGI. It is a community of creative women who have an entrepreneurial spirit and live in the Pancoran area (South Jakarta-Indonesia). This community has 30 female members who have various types of micro businesses. The third stage was observasion and mapping condition of each community member. At this stage community members were asked to conduct a business Strengths, Weakness, Opportunities and Threats (SWOT) analysis and fill out online and offline survey through

\footnotetext{
${ }^{13}$ Alimul Muniroh, and Moh Nasrul Amin. "Perempuan Dan Sekolah Lapang Hasil Laut". Engagement: Jurnal Pengabdian Kepada Masyarakat 4, no. 1 (2020): 116 - 137.

${ }^{14}$ Rachel Pain, Geo Whitman and David Milledge, and Lune Rivers Trust. Participatory Action Research Toolkit: An Introduction to Using PAR as an Approach to Learning, Research and Action. Department of Geography, Durham University. Durham-UK, 2012.
} 
Focus Group Discussion. The fourth stage was exploration in depth interview with each community member. Some community members will get a visit and direct assistance according to the their problems. At this stage we involve students and lecturers across departments. The fifth stage was designing proper training model to solve community problems. The training materials was prepared acording to the observation and SWOT analysis results that will be delivered and coached by academics and experties. The output of each activity was also determined to measure how big is the impact for the community members. All of the programs carried out for six months. Whole Community service methodology flow described by Figure 1.

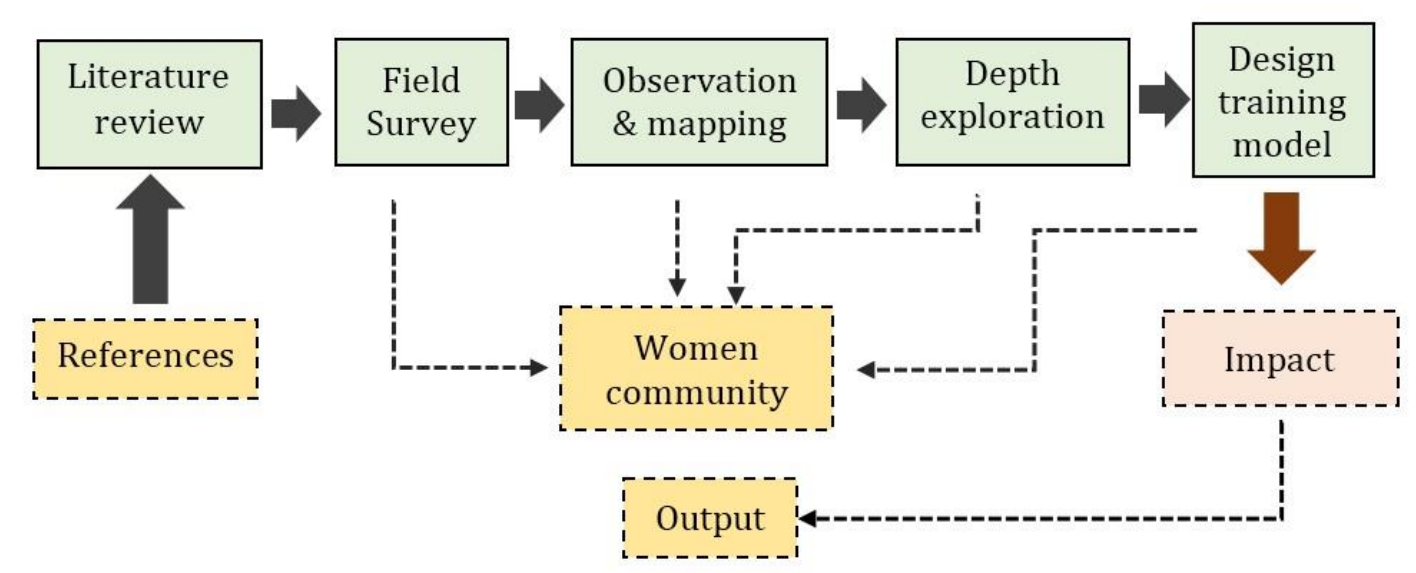

Figure 1. Community Service Methodology Flow

\section{Results}

\section{Observation and Mapping}

As we can see from Figure 2. data collection showed that more than $50 \%$ community members works in food business area. Food as basic human need will always be in demand all the time followed by human population growth. Food also has a strategic role for a country because it can affect the social, economic and political conditions of the country. Referring to the 2015-2015 food outlook analysis published by the ministry of trade $(2014)^{15}$, business in the food sector become important due to changes of global conditions that demand independence. The changes are reflected in: international food prices that experienced a drastic jump and uncertain, there is a tendency for selfish countries; prioritizing their own needs, the competition for the use of agricultural commodities (food vs feed vs. energy), the occurrence of the global economic recession, and the invasion foreign food ("westernization diet").

\footnotetext{
${ }^{15}$ Ministry of Trade. Food Outlook Analysis 2015-2019. Pusat kebijakan perdagangan dalam negeri badan pengkajian dan pengembangan kebijakan perdagangan kementerian perdagangan, 2014.
} 


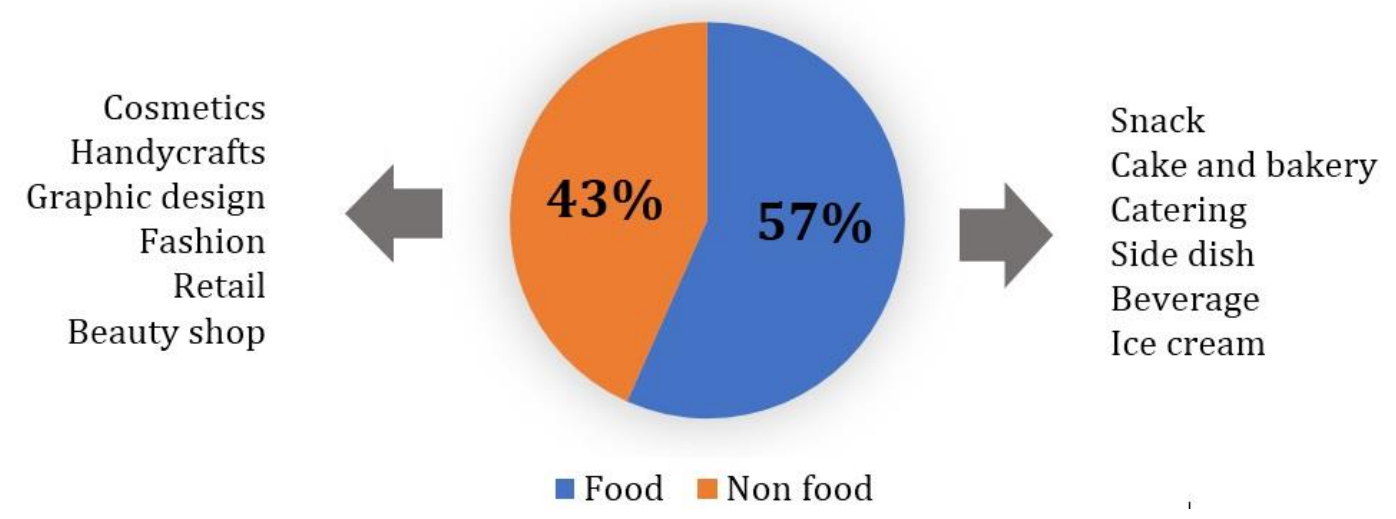

Figure 2. Percentage of KOTA PELANGI Microentrepreneurship Area Community Members

Food business activities includes food stalls, caravans or the like used for temporary events, mobile food vans, boats on which catering functions are held, food premises in shopping centers, street frontage businesses, school canteens, caterers, home businesses etc. The food business categories of community members ranging from snacks, cake and bakery, catering, side dish, and beverage. There are some critical success factors of the food service industry, including adaption to locality, food quality, service, facilities, place to be, and sales incentive program ${ }^{16}$. Community leader can create small marketing team research to find to help them better understand of market characteristic and consumer behavior.

\section{Strengths, Weakness, Opportunities and Threats (SWOT) analysis}

Competition in running business activities is never ending story where experienced by not only large companies but also small and medium enterprises ${ }^{17}$. They need entrepeneurial competencies to start a business and managerial skills to grow the business. Planning is the first stage in any activity including business planning. One of the basic analysis tools in planning is to use the SWOT method. The SWOT method analyzes internal strengths (strengths) and weaknesses as well as the analysis of opportunities and threats. SWOT is a simple way to estimate the best way to do a strategy. SWOT implementation is very dependent on the situation and conditions, both internal and external conditions. Figure 3. Shows that product quality becomes the most strength of microentrepreneur community members. Quality can be interpreted as the result of a subjective assessment in which customers compare their expectations with the reality of

\footnotetext{
${ }^{16}$ Spyridon Mamalis. "Critical Success Factors of the Food Service Industry". Journal of International Food \& Agribusiness Marketing 21 (2009): 191-206.

${ }^{17}$ Diana Eravia, Tri Handayani, and Julina. "The Opportunities and Threats of Small and Medium Enterproses in Pekanbaru: Comparison between SMEs in Food and Restaurant Industries". ProcediaSocial and Behavioral Science 169 (2015): 88-97.
} 
product quality. Results showed that customers satisfaction key success of the business ${ }^{18}$. Having good product quality is good strengths for food business. The community members need to retain or even increase their product quality to gain more consumers. More important is how to deliver information that their product is good in quality by using good packaging and marketing language.

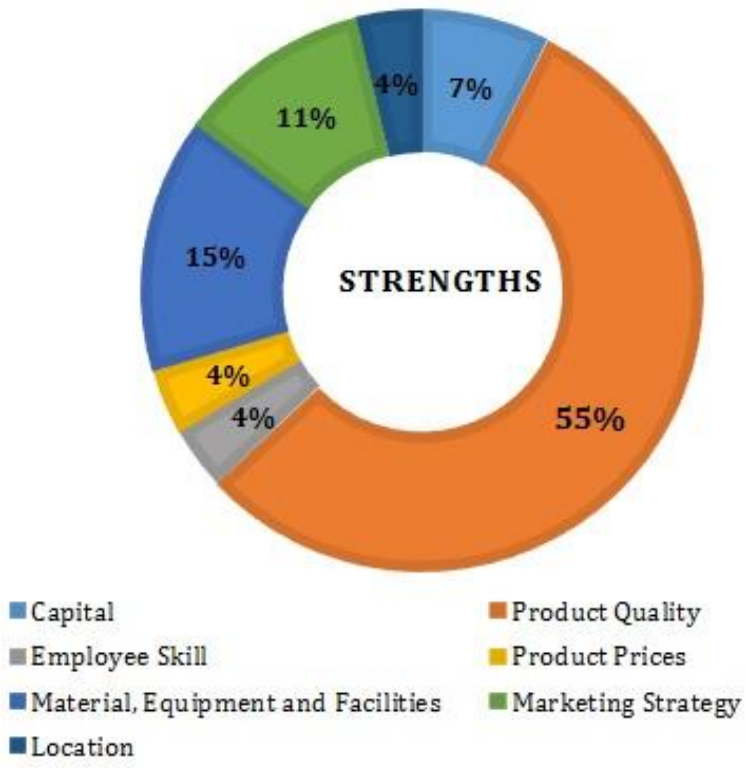

Figure 3. Strengths of KOTA PELANGI Microentrepreneur Community members

Small-scale businesses usually have smaller budgets than large companies due to the source of capital budget is usually only sourced from business owners. The biggest budget is allocated for production activities, while marketing is sometimes overlooked. As seen in Figure 4. Marketing strategy becomes the biggest weakness of micoentrepreneur members. Common challenges of small business owners face when it comes to marketing might include: do not have the right marketing plan, limited resources, little budget, and do not enough time to do marketing activities. Promotion is one of the most widely applied marketing methods where promotion is the first meeting of seller message to potential customers. Through promotional message, seller attempts to inform and persuade the customers about the product. There are several ways to promote the product by sales promotion, public relation and publicity, direct marketing, personal selling events/exhibition and experience. One of marketing strategy is to use a brand, where brand convey a message of confidence, quality and reliability to target market ${ }^{19}$. But brand building requires not a small amount of money. Even though, the

\footnotetext{
${ }^{18}$ Petr Suchanek, Jiri Richter, and Maria Kralova. “Customer Satisfaction with Quality of Products of Food Business". Progue Economic Papers 26, no. 1 (2017): 19-35.

${ }^{19}$ Sheetal, Sangeeta, Rajiv Kumar. "Marketing Strategies of Small and Medium Enterprises: A Sample Survey”. IJMRS's International Journal of Mannagement Sciences 1, no. 2 (2012).
} 
community member should start to give more attention and invest their capital for branding to help their marketing result increase.

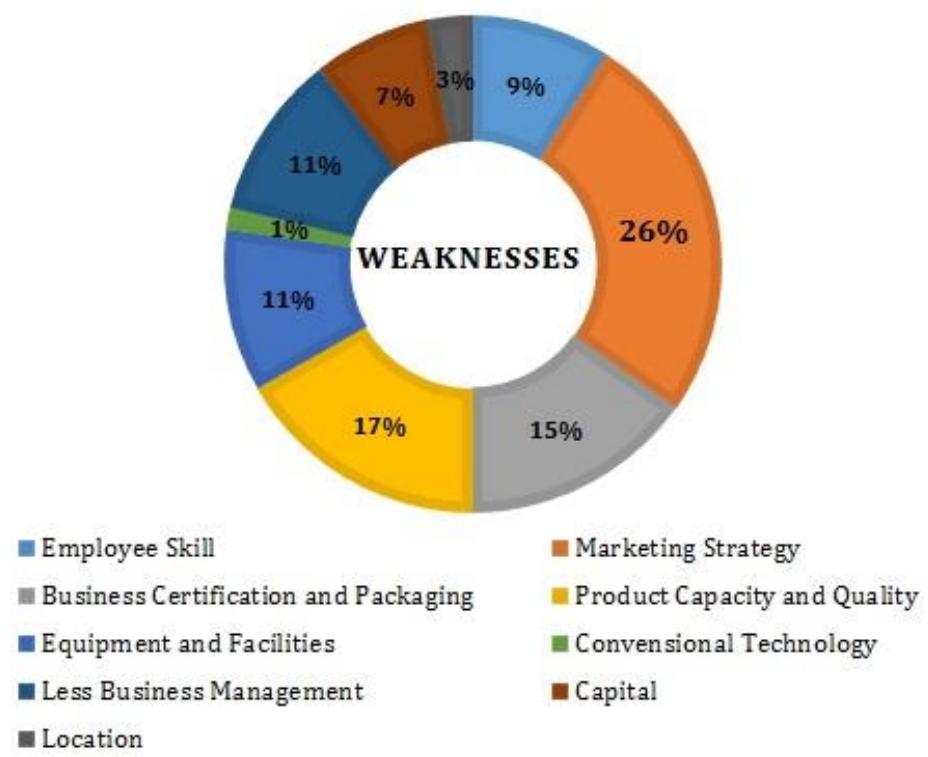

Figure 4. Weaknesses of KOTA PELANGI Microentrepreneur Community members

Opportunity is the advantage that come from outside. While the threat is a shortcoming that come from outside. To find out the opportunities and threats research market of the product is needed. Figure 5. Shows that high demand of product become the biggest opportunity to microentrepreneur community members. Volume and quality food and nutrition consumption in the household influenced by economic conditions, knowledge and culture of the community ${ }^{20}$. Community member should understand that ensuring food and nutrition security for human right are moral imperatives, critical challenges and responsibility of multiple stakeholders.

${ }^{20}$ Kaman Nainggolan. "Persoalan Pangan Global dan Dampaknya Terhadap Ketahanan Pangan Nasional”. Pangan 20, no. 1 (2011): 1-13. 


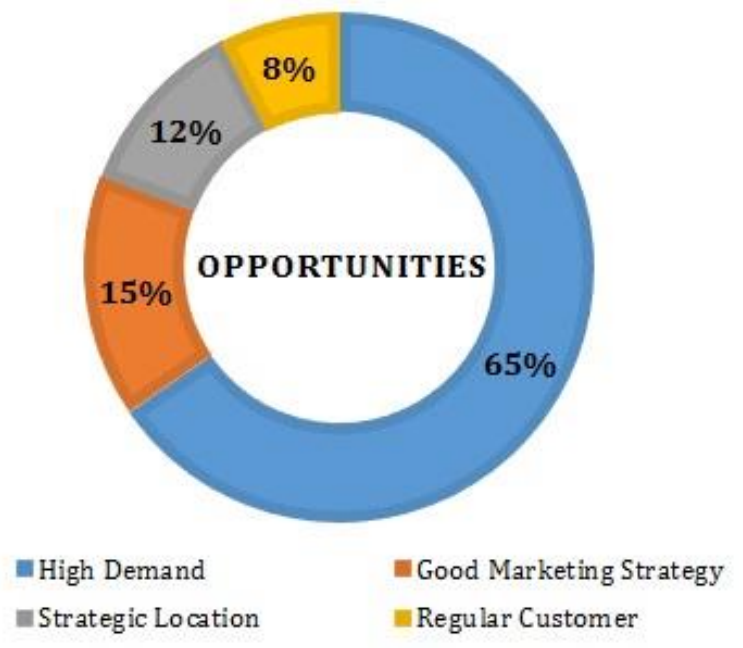

Figure 5. Opportunities of KOTA PELANGI Microentrepreneur Community members

Figure 6. Shows that competitor is the biggest treat for microentrepreneur community members. The development of the global market for food products is characterized by the diversion of the function of food as an alternative energy ingredient. This situation makes food prices competitive and causes a decrease in availability ${ }^{13}$. Even though, competitor can be a good driving force to make innovation and produce better product quality. KOTA PELANGI need to make small team from the member assisted with expert to analyze the competitor. Competitor analysis has become a necessity for entrepreneurs, both for beginners and expert entrepreneurs who will open new branches.

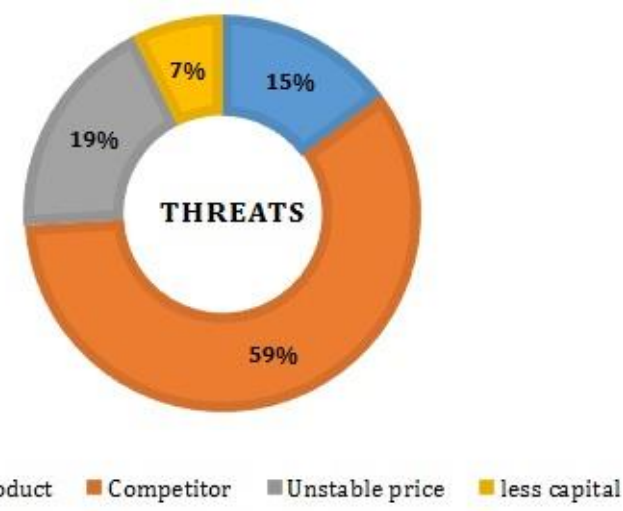

Figure 6. Treats of KOTA PELANGI Microentrepreneur Community members

\section{Microenterpreneur Community Problems}

There is no standart format for a business plan, but there are many common components, i.e business goals and objectives, descripsion of product, market and competition assessment, marketing strategies, production plan and financial analysis. If those components do not manage properly, it will become problems. Based on the results 
of observations and SWOT analysis, a lot of problems faced by KOTA PELANGI Microentrepreneur Community members. But It is impossible to solve all the problems in the same time. Therefore, only five biggest problems used as main consideration in creating training and coaching programs. As can be seen in Figure 7, the problems consist of marketing strategy, product quality and innovation, capital, equipment and facilities, employee and business management, business certification and packaging.

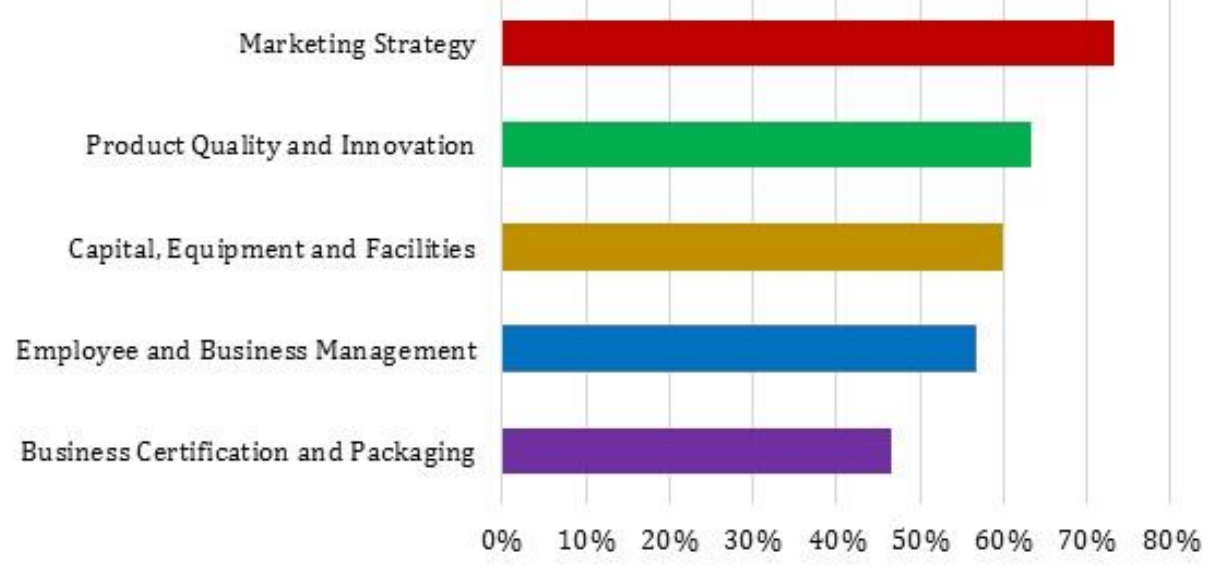

Figure 7. Five Problems Priority of KOTA PELANGI Microentrepreneur Community

\section{Model Program}

The proposed schematic program to solve the five priority problems can be seen at Figure 8. The first stage is product quality and innovation training. Product quality also inludes food safety and innovation includes product development in reformulation or packaging ${ }^{19}$. Bazar or exhibition is one of supporting program for this stage. The exhibition allows products innovation to be introduced and tested on consumer acceptance levels. The second stage is marketing strategy training. Marketing plan design for small businesses consit of market research, product life cycle, promotion techniques, and channels of distribution ${ }^{21}$. The third stage is capital, equipment and facilities training. The government has many institutions that provide financial assistance to small businesses. The community member should regularly access those information's. The fourth stage is employee and business management training. Management is basically a regulating activity resources (material, human, machinery and equipment, capital funding) through the help of others, to achieve specific purpose ${ }^{22}$. In addition, good organizational management in a business will make the business work effectively and efficiently. The fifth stage is business certification and packaging training. Product labeling and packaging should provide name of the food orstatement of identity, net

${ }^{21}$ V. Sharma. "Creative Marketing for small businesses". IOSR Journal of Business and Management (IOSR-JBM) 16, no. 7 (2014): 69-77.

${ }^{22}$ Sri Maryanti. Manajemen Usaha Kecil. Deepublish. Yogyakarta, 2017. 
quantity of contents or amount of product, nutrition facts, ingredient and allergen statement, name and address of the manufacturer, packer, or distributor. The existence of a business certification will have an influence on consumers' trust in the quality of the products produced. This will provide benefits and increase the value of product marketing. To accelerate the program it would be better to join with related institution such as National Food and Drug Agency. 


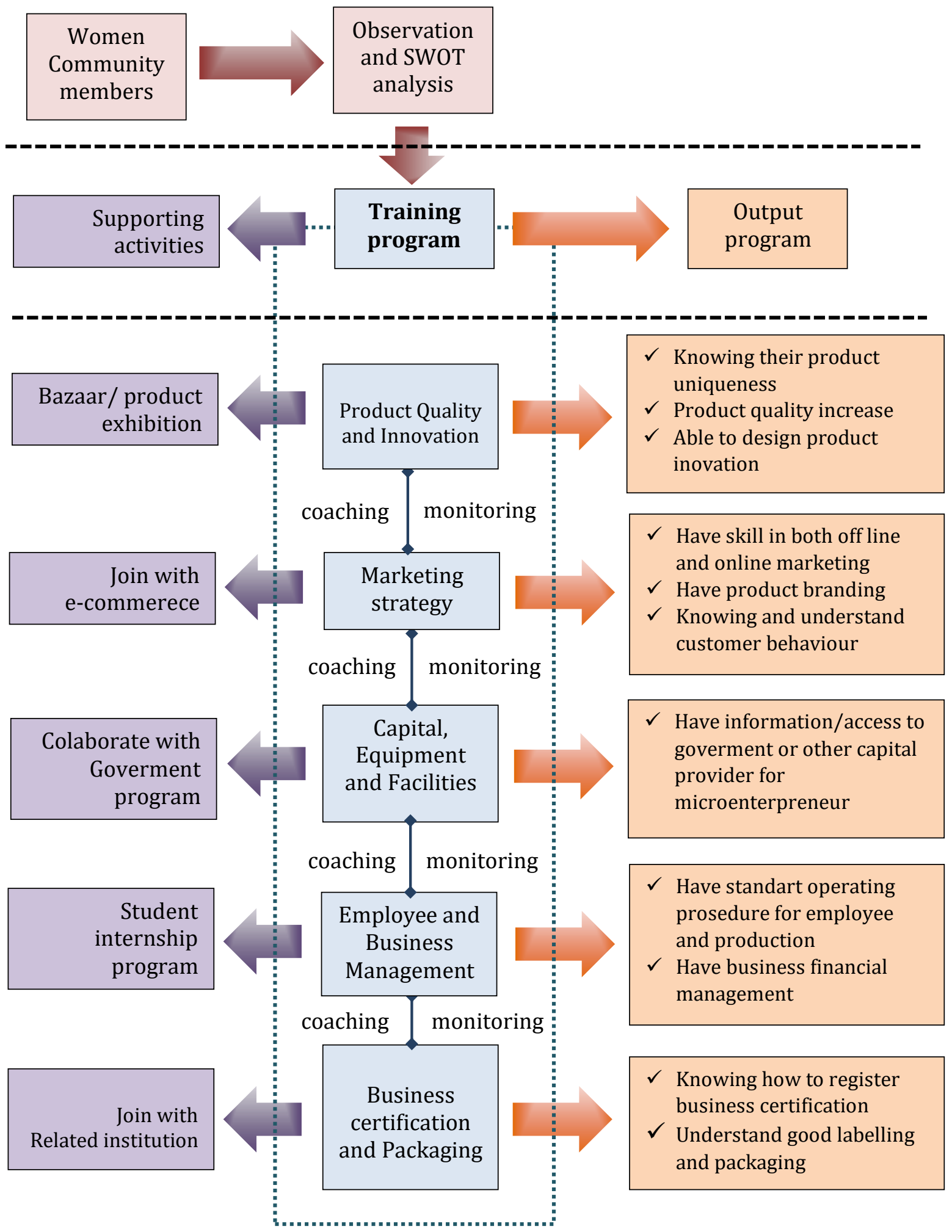

Figure 8. Schematic Training and Coaching Programs For KOTA PELANGI Microentrepreneur Community Members 


\section{Discussions}

Women enterpreneurship grows rapidly due to no longger barrier between run a business and become enterpreneur. The rapid growth of food business is infulenced by several factors such as increasing of health awareness, economic growth of middle class, modern technology and modern retail store. Based on results analysis, food becomes the biggest item that is chosen by KOTA PELANGI members as sellable item. Working in food business area is not easy. There are some people gain success but also some of them failed. To run this business need SWOT analysis to help the business actors manage their business properly. The main purpose of a SWOT analysis is to optimize strengths and minimize weaknesses, and take advantage of opportunities that arise and warm up the threats that come. In the business world, changes in conditions and situations will often be encountered. These changes must be addressed by analyzing SWOT so business can survive. From SWOT analysis, marketing strategy becomes the biggest weakness of KOTA PELANGI micoentrepreneur members. The rate of increase in food demand for some commodities is faster than the rate of increase in production. Population growth is dominated by developing countries and occurs in urban areas, especially in Jakarta. In addition, hunger and malnutrition are cause of death. Consumption of food with sufficient nutrition and balanced is one important factor which determines the level of health and human intelligence. Therefore, it is important for KOTA PELANGI members make innovation in their product to create healthy food. Besides that, competitor is the biggest treat for microentrepreneur community members. This is important considering that by analyzing competitors, market positioning, value propositions and marketing strategies can be carried out to survive in the business competition. Still, unstable price also become treats microentrepreneur community members.

After knowing their SWOT, As the first problem, microentrepreneur community members should understand their main problems. Based on previous results, they have big problem in marketing strategy. Marketing strategy is not a standard process that applies for certain time, but it is a developing process and needs to be updated at any time. Limited market access is one part of market problem in KOTA PELANGI, it may caused the products not to be marketed competitively both in local or national markets. To enlarge the marketing spread, marketing strategy can be done off line and online. The opportunity to join with e-commerce can be used as supporting program of this stage. The second problem of KOTA PELANGI are product quality and innovation. Entrepreneurs must realize that consumers' demands always changing over time. The consumer expect for more food quality, safety, shelf life, reducing wastage, hight nutritional value, palatability, and convenience. The real product development process is how to bring together what consumer expect and demand to the technical capacity of the 
food producer, and emerging knowledge from food science research ${ }^{23}$.

The third problem are capital, equipment and facilities. Capital is one of the most critical inputs for all business enterprise, whether it is for large or small enterprises. Sources of finance may come from internal such as personal saving or external such as loans, subsidies and government grants flows ${ }^{24}$. Problems that confront small businesses involve the ability to access finance, market access and marketing, small business management and access to information. Difficulties in small businesses accessing capital resources due to limited information and the ability to penetrate these sources of capital. At this program, collaborate with government as one of capital provider is good option. The Fourth problem are employee and business manajemen. An entrepreneur must make sure the business wheels run well and of course reach the targets that have been made. For this reason, implementing business management is a mandatory thing to do. Business management is not only applied to large businesses, even all business lines of small businesses should implement business management. Moreover look for good employees to work together as a management function is an important aspect to achieve business goals. Because the employees are company assets not a labor. Due to wide aspect of management, it is possible for student internship program to assist the community arrange the business management program. In addition, one of business management aspect is good financial accounting management. A good balance sheet will make it easier to analyze the profit and loss and value of business assets. The fifth problem are business certification and packaging. Business must have legal certification, not only large scale businesses but also small-scale businesses. Legal certification give legal protection, give easy financing to various bank and non-bank financial institutions, give opportunity to get training or coaching businesses etc. Thee main function of food packaging are to protect food products from outside environment and damage, to contain the food, and to provide information to consumer about ingredient and nutritional information. The second function are traceability, convenience, and tamper indication. The packgaging should be able to maintains food safety and and minimizes environmental impact ${ }^{25}$.

By considering observation, SWOT analysis, and problems of KOTA PELANGI community members, there are several solutions offered in this program, including through a gradual approach of training, coaching and monitoring as depicted in Figure 8. There are at least five training, coaching and monitoring activities. The first stage is product quality and innovation training. The second stage is marketing strategy training. The third stage is capital, equipment and facilities training. The fourth stage is employee

\footnotetext{
${ }^{23}$ Ray Winger, and Gavin Wall. Food product innovation A background paper. Agricultural And Food Engineering Working Document FAO. 2006.

${ }^{24}$ Mohammed Ahmar Uddin. "Problem faced by micro, small and medium enterprises in raising debt capital". Proceeding of The Social Sciences Research ICSSR, Sabah, Malaysia. 2014.

${ }^{25}$ Kenneth Marsh, and Betty Bugusu. "Food Packaging-Roles, Materials, and Environmental Issues". Journal of Food Science 72, no. 3 (2017): 39-55.
} 
and business management training. The fifth stage is business certification and packaging training. Those programs proposed to solve the problems and increase the knowledge of KOTA PELANGI community members, so they can manage their business properly.

\section{Conclusion}

Based on observation and SWOT analysis research found five priority problems faced by women's microentrepreneurs community. There are several solutions offered to reduce those problems, including through a gradual approach of training, coaching and monitoring programs. Still, due to there are several aspect to be considered such as social, educational, economic, and cultural conditions of community members, the program was designed not only to implement as a training system, but it should be accompanied by supporting programs, coaching and monitoring regularly. In addition, several activities and colaboration from various stakeholders are also needed to support the success of the program. This model is a small part of efforts to improve women's empowerment through microentrepreneurship. If the program is implemented properly, it is expected that the community will get the output as significant impact.

\section{Acknowledgements}

This community service was conducted in Pancoran, South Jakarta-Indonesia colaborated with Universitas Bakrie. This community service was funded by RISTEKDIKTI No 035/KM/PNT/2018 and Universitas Bakrie. The authors would like to thanks to KOTA PELANGI Comunity members and all people who involved in this program.

\section{References}

Ade Octavia, Ida Masriani, and Sry Rosita. "Pemberdayaan Masyrakat Melalui Optimalisasi Program Bank Sampah Dengan Bantuan Teknis dan Manajemen Usaha Pada KSM Aneka Limbah dan KSM Maidanul Ula Kota Jambi". Jurnal Pengabdian pada Masyarakat 30, no. 3 (2015).

Aleksandra Vujko, Tatiana N. Tretiakova, Marko D. Petrovic, Milan Radovanovic, Tamara Gajica, and Darko Vukovic. "Wowen's empowerment through selfemployment in tourism". Annals of Tourism Research, 76 (2019): 328-330.

Alessandra Galie, Nils Teufel, Amy Webb Girard, Isabelle Baltenweck, Paula Dominguez-Salas, Mindy J. Price, Rebecca Jones, Ben Lukuyu, Luke Korir, Ilana G. Raskind, Kristie Smith, and Kathryn M. Yount. "Women's empowerment, food security and nutrition of pastoral communities in Tanzania". Global Food Security 23 (2019): 125-134. 
Alimul Muniroh, and Moh Nasrul Amin. "Perempuan Dan Sekolah Lapang Hasil Laut". Engagement: Jurnal Pengabdian Kepada Masyarakat 4, no. 1 (2020): 116 - 137.

Besse Wediawati and Rike Setiawati. "IbM Kelompok Usaha Bersama Perempuan Kepala Keluarga (KUBE-PEKKA) Di Kecamatan Telanai Pura Kota Jambi”. Jurnal Pengabdian pada Masyarakat 30, no. 1 (2015).

Diana Eravia, Tri Handayani, and Julina. "The Opportunities and Threats of Small and Medium Enterproses in Pekanbaru: Comparison between SMEs in Food and Restaurant Industries". Procedia-Social and Behavioral Science 169 (2015): 8897.

Fahri Ozsungur. "A research on women's entrepreneurship motivation: Sample of Adana Province”. Women's Studies International Forum 74 (2019): 114-126.

Farawa Morshed. "Impact of Women Enterpreneurship on Women Empowerment in Bangladesh". Journal of Economics and Sustainable Development 6, no. 1 (2015): 1-9.

Harri Santoso, Anita, Muliadi and Debi Agus Mayanti "Community Economic Empowerment through Cultivation of Enceng Gondok Program Using Community Engagement Program Approach in West Aceh Regency Post Conflict and Natural Disaster Eartquake and Tsunami 2004". Jurnal Pengabdian pada Masyarakat 3, no. 2 (2018).

Kaman Nainggolan. "Persoalan Pangan Global dan Dampaknya Terhadap Ketahanan Pangan Nasional". Pangan 20, no. 1 (2011): 1-13.

Kenneth Marsh, and Betty Bugusu. "Food Packaging-Roles, Materials, and Environmental Issues”. Journal of Food Science 72, no. 3 (2017): 39-55.

Ministry of Trade. Food Outlook Analysis 2015-2019. Pusat kebijakan perdagangan dalam negeri badan pengkajian dan pengembangan kebijakan perdagangan kementerian perdagangan, 2014.

Mohammed Ahmar Uddin. "Problem faced by micro, small and medium enterprises in raising debt capital". Proceeding of The Social Sciences Research ICSSR, Sabah, Malaysia. 2014.

Petr Suchanek, Jiri Richter, and Maria Kralova. “Customer Satisfaction with Quality of Products of Food Business”. Progue Economic Papers 26, no. 1 (2017): 19-35.

Rachel Pain, Geo Whitman and David Milledge, and Lune Rivers Trust. Participatory Action Research Toolkit: An Introduction to Using PAR as an Approach to Learning, Research and Action. Department of Geography, Durham University. Durham-UK, 2012. 
Ray Winger, and Gavin Wall. Food product innovation A background paper. Agricultural And Food Engineering Working Document FAO. 2006.

Sheetal, Sangeeta, Rajiv Kumar. "Marketing Strategies of Small and Medium Enterprises: A Sample Survey". IJMRS's International Journal of Mannagement Sciences 1, no. 2 (2012).

Sholahuddin, Josua Parulian Hutajulu, and Evi Gusmayanti. "Peningkatan Produktivitas Usaha Pengeringan Tepung Sagu Masyarakat melalui Introduksi Teknologi Tepat Guna di Kalimantan Barat". Jurnal Pengabdian pada Masyarakat 3, no. 2 (2018).

Sophia Friedson-Ridenour, and Rachael S. Pierotti. “Competing priorities: Women's microenterprises and household relationships". World Development 121 (2019): 53-62.

Spyridon Mamalis. "Critical Success Factors of the Food Service Industry". Journal of International Food \& Agribusiness Marketing 21 (2009): 191-206.

Sri Maryanti. Manajemen Usaha Kecil. Deepublish. Yogyakarta, 2017.

Sunarti., Endriani, and Ajidirman. "Pemberdayaan Masyarakat Berbasis Teknologi Model Rumah Pangan Lestari di Kecamatan Kumpeh Ulu”. Jurnal Pengabdian pada Masyarakat 30, no. 1 (2015).

Tona Aurora Lubis, Zulkifli, and Erwita Dewi "Peningkatan Ketrampilan Manajemen dan Softskill Penjual Jamu Gendong di Kota Jambi". Jurnal Pengabdian pada Masyarakat 30, no. 3 (2015).

V. Sharma. "Creative Marketing for small businesses". IOSR Journal of Business and Management (IOSR-JBM) 16, no. 7 (2014): 69-77.

Yusma Damayanti, Suandi, and Emi Kernalis. "Pelatihan dan Penyuluhan Pembuatan Telur Itik Asin Dalam Upaya Pengembangan Kewirausahaan Baru di Desa Tanjung Harapan Cupak Kecamatan Danau Kerinci Kabupaten Kerinci”. Jurnal Pengabdian pada Masyarakat 30, no.4 (2015). 